\title{
POVO DO MANGUE: ANTROPIZAÇÃO E VESTÍGIOS ARQUEOLÓGICOS NA PENÍNSULA ODIVELENSE
}

PAULO ROBERTO DO CANTO LOPES ${ }^{1}$

UFPA, BRASIL

JOSÉ GUILHERME DOS SANTOS FERNANDES ${ }^{2}$

UFPA, BRASIL

FERNANDO MONTEIRO DA SILVA

UEPA, BRASIL

\begin{abstract}
RESUMO: As pesquisas arqueológicas na costa norte paraense foram desenvolvidas desde o século XIX e ampliadas na segunda metade da década de 1960, confirmando a antiguidade nessa região há pelo menos 5.000 anos. Apesar da importância dos sitios e vestígios arqueológicos referentes aos pescadores-coletores e agricultores, os estudos sobre sambaquis e sítios de terra preta arqueológica ainda são pontuais na costa norte paraense. Este artigo apresenta discussões e dados preliminares acerca da retomada das pesquisas arqueológicas nesse espaço amazônico, com metodologia baseada na bibliografia arqueológica, nas pesquisas de campo, nos relatos orais de moradores locais e documentos sobre povoamentos na colonização da região nordeste e costeira do Estado do Pará, atentando para a incipiente pesquisa a respeito de sítios com terra preta arqueológica em áreas (intra)manguezais, ecossistema predominante na costa amazônica. Os estudos levaram a análises de fontes documentais e à visualização de materialidades, observadas no município de São Caetano de Odivelas (PA), com fortes indícios da presença indígena pré-colombiana nos vestígios até então encontrados na superficie do terreno, além de vestígios históricos. Pode-se configurar nova dinâmica dos movimentos populacionais na costa norte do Brasil, com indícios de contatos entre os povos pré-colombianos do nordeste brasileiro e os povos provenientes das Guianas.
\end{abstract}

PALAVRAS-CHAVE: antropização; península odivelense; arqueologia na Amazônia; manguezais; pesquisa colaborativa.

ABSTRACT: Archaeological research on the north coast of Pará, in Brazil, has been conducted since the 19th century and expanded in the second half of the 1960s, confirming antiquity in this region less than 5,000 years ago. Despite the importance of archaeological sites and garments related to fisherman-gatherers and farmers, studies on sambaquis and archaeological black earth maps are punctual on the north coast of Pará. This article presents discussions and preliminary data about the resumption of archaeological research in this Amazonian space, having

\footnotetext{
${ }^{1}$ Doutor em Arqueologia (Museu Nacional/UFRJ, 2016). Professor Convidado do Programa de PósGraduação em Estudos Antrópicos na Amazônia (PPGEAA/UFPA) e membro do COLINS (Colaboratório de Interculturalidades, Inserção de Saberes e Inovação Social)/UFPA. E-mail: paulocanto6@gmail.com

${ }^{2}$ Doutor em Letras (UFPB, 2004). Professor Associado da Universidade Federal do Pará e do Programa de Pós-Graduação em Estudos Antrópicos na Amazônia (PPGEAA/UFPA) e coordenador do COLINS (Colaboratório de Interculturalidades, Inserção de Saberes e Inovação Social)/UFPA. E-mail: mojuim@uol.com.br

${ }^{3}$ Mestrando do Programa de Pós-Graduação em Estudos Antrópicos na Amazônia (PPGEAA/UFPA e membro do COLINS (Colaboratório de Interculturalidades, Inserção de Saberes e Inovação Social)/UFPA. E-mail: monteirosmg@gmail.com

LOPES, Paulo Roberto do Canto; FERNANDES, José Guilherme dos Santos; SILVA, Fernando Monteiro da. Povo do mangue: antropização e vestígios arqueológicos na península odivelense. Espaço Ameríndio, Porto Alegre, v. 14, n. 1, p. 265-289, jan./jul. 2020.
} 
methodology based on archaeological bibliography, field research, oral reports from local residents and documents about settlements in the colonization of the northeast and coastal region of the State of Pará. , paying attention to the incipient research about sites with archaeological black earth in (intra) mangrove areas, predominant ecosystem on the Amazon coast. The studies led to the analysis of documented sources and discovered material evidence, observed in the city of São Caetano de Odivelas (PA), with strong indications of the pre-Columbian indigenous presence in the traces that were found on the surface of the land, as well as historical traces. New dynamics of population movements on the north coast of Brazil can be configured, with indications of contacts between the pre-Columbian peoples of northeastern Brazil and those from the Guianas.

KEYWORDS: anthropization; odivelense peninsula; archeology in the Amazon; mangroves; collaborative research. 


\section{Introdução}

Apesar do desenvolvimento da pesquisa arqueológica na região amazônica ser antigo, percebe-se uma invisibilidade especialmente na zona costeira do estado do Pará, no cenário dos estudos arqueológicos no Brasil. Os vestígios arqueológicos, na região costeira, foram localizados especialmente nas bordas de manguezais e campos salinos, ou em áreas de transição entre manguezais e planalto. Pouco, até então, foi pesquisado acerca da construção de sambaquis e/ou implantação de sítios de terra preta arqueológica (TPA) em áreas de terra firme encontradas em meio a manguezais.

A ausência de uma história da arqueologia dos grupos sociais estabelecidos na costa norte paraense - arqueologia pré-colombiana e arqueologia histórica - tem levado as populações locais ao desconhecimento de que suas identidades sejam compostas também por povos originários, em tensões e acordos com povos transplantados pelos processos colonizadores, ou mesmo com outros povos originários contatados. Esta visão é contrária à do nosso projeto de investigação, homônimo ao título deste trabalho, que aponta que as populações amazônidas pré-colombianas realizaram grandes movimentos migratórios, resultando em trocas de produtos e em marcações territoriais com finalidade bélica e de proteção de seus espaços. Considerando-se as permanências e movências de populações desde os períodos pré-colombiano e colonial, pode-se dizer que a aparente diáspora entre as comunidades do litoral paraense e os povos indígenas marajoaras - a oeste - e os Tupinambá - do nordeste e leste do Pará nunca existiu, pois os fluxos migratórios eram constantes e intensos, como poderão atestar os vestígios - seja a cerâmica ou os instrumentos em rocha - oriundos de outras regiões, quando consideramos a composição desse material.

Neste sentido, o município de São Caetano de Odivelas, na microrregião do Salgado paraense, parece-nos promissor como campo de coleta de vestígios para uma arqueologia pré-colombiana e histórica, pois, além de remontar ao século $\mathrm{XVIII}{ }^{4}$, enquanto estabelecimento geopolítico, nunca é demais afirmar que as vilas e cidades portuguesas nascentes naquele século quase sempre se instituíam a partir de algum assentamento indígena. Este indício pode ser atestado em requerimento disposto no Arquivo Histórico Ultramarino, em Lisboa (Portugal), no documento 7607, Caixa 96 - Conselho Ultramarino: em 23 de novembro de 1786, o indígena Antônio José, filho da índia Andreza, requer à Majestade seu direito natural e divino à liberdade, para que possa se ausentar de sua aldeia e trabalhar em fazenda de gado na ilha Grande de Joanes (atualmente ilha de Marajó); o detalhe é que o indígena era casado com a índia Francisca Lopes, "natural do Lugar de Odivelas, Comarca e

\footnotetext{
${ }^{4}$ Segundo Baena (2014), em seu Ensaio corográfico sobre a Província do Pará, datado de 1839, a cidade de São Caetano de Odivelas, então conhecida unicamente como Lugar de Odivelas, teria sido criada em 1757, "sobre terra pouco eminente da margem esquerda do assaz vistoso rio Tabatinga" (p. 241), rio este hoje conhecido como Mojuim.

LOPES, Paulo Roberto do Canto; FERNANDES, José Guilherme dos Santos; SILVA, Fernando Monteiro da. Povo do mangue: antropização e vestígios arqueológicos na península odivelense. Espaço Ameríndio, Porto Alegre, v. 14, n. 1 , p. 265-289, jan./jul. 2020.
} 
Bispado do Grão Pará". Isso atesta que naquele longínquo ano já se admitia a existência da povoação, ou lugar (designavam-se assim pequenas vilas em que não havia Câmara Municipal), que daria origem a atual cidade odivelense, com o reconhecimento de ser território de nascimento de indígenas.

Nossa hipótese é que houve a utilização estratégica de áreas intramanguezais para o domínio territorial e a economia de subsistência multivariada. Neste caso, ocorreu a produção de alimentos - com a pesca, a coleta, a caça, o manejo de espécies de vegetais (plantas frutíferas e medicinais) ou as plantações - e, ainda hoje, figuram no território litorâneo da Amazônia paraense, áreas de pequenas florestas de terra firme e florestas de manguezais, próximas de rios ou riachos de água doce que desaguam em marés de água salgada. Nestes cursos de água, por vezes, estão rochas, formando pequenas corredeiras, que são retentoras de peixes e crustáceos, mas que servem também como suporte para as bacias de polimento (afiadores e alisadores). Portanto, é relevante o estudo dessas regiões no entorno de estuários, como a exemplo da península odivelense ${ }^{5}$. Afirma Rostain, acerca da Guiana Francesa, região no estuário amazônico e no mesmo ecossistema em que se insere o sítio foco de nossas pesquisas, que:

Presque tous les villages amérindiens littoraux visités par les chroniqueurs étaint situés dans l'estuaire de fleuves. Cette localisation charnière semblait s'insérer dans un réseau de relations intertribales. D'une part, ces sites, face à la mer, étaient des points d'escale des voyageurs maritimes et, d'autre part, ils contrôlaient l'entrée et la sortie des terres par les cours d'eau (...). De tels villages représentaient des centre de communication et des foyers privilégiés d'informations sur les mouvements de troupes et de commerçants. Les chefs de nation y résidaient généralement, accueillaient les arrivants, organisaient les expéditions guerrières et commerciales, géraient le territoire (2016, p.82).

Os locais estratégicos selecionados para a construção e/ou implantação de sítios arqueológicos relacionam-se ao domínio do território usado ${ }^{6}$, uma vez que a localização dos sítios parte de

\footnotetext{
${ }^{5}$ A designação de península odivelense, nesta pesquisa, refere-se ao território do município de São Caetano de Odivelas, estado do Pará, na Amazônia brasileira, localizado na mesorregião do Nordeste do Pará, microrregião do Salgado paraense, e situado entre a baía do Marajó, a oeste; o oceano Atlântico, ao norte; o estuário do rio Mojuim, a leste; e o rio Barreta, ao sul. Esta área confunde-se com o território da Reserva Extrativista Marinha Mocapajuba, instituída por Decreto Presidencial de 10/10/2014 e Diploma Legal de Criação DEC S/N 10/10/2014 (ICMBio). Geograficamente é constituída de manguezais, matas de terra firme e campos salinos, sendo tributária de vários cursos d'água importantes para o ecossistema local, como os rios Pererú, Barreta, Camapú e Mojuim.

${ }^{6} \mathrm{Na}$ reflexão de Santos (2005), o território usado não é apenas o conjunto dos sistemas naturais e de coisas superpostas, uma vez que "[...] é o fundamento do trabalho; o lugar da residência, das trocas materiais e espirituais e do exercício da vida." (SANTOS, 2007, p.14). De acordo com Lopes (2012, p.39), "O território é tanto o resultado do processo histórico quanto a base material e social das novas ações humanas." Onde a "[...] identidade se traduz no sentimento de pertencimento, ou seja, pertencer àquilo que lhe pertence [...]". LOPES, Paulo Roberto do Canto; FERNANDES, José Guilherme dos Santos; SILVA, Fernando Monteiro da. Povo do mangue: antropização e vestígios arqueológicos na península odivelense. Espaço Ameríndio, Porto Alegre, v. 14, n. 1, p. 265-289, jan./jul. 2020.
} 
planejamento, organização do grupo, das normas e escolhas de materiais, demonstrando o domínio bélico e político da escolha ao localizarem-se em espaço estuarino e/ou interfluvial - no caso da península odivelense (IMAGEM 1) - entre a baía do Marajó e a foz dos rios Mojuim e Mocajuba, por onde frequentemente existe o trânsito de embarcações e contingentes que vem do mar e adentram as localidades de rios, ou vice-versa.

Figura 1: Localização geográfica da Península Odivelense e municípios do entorno

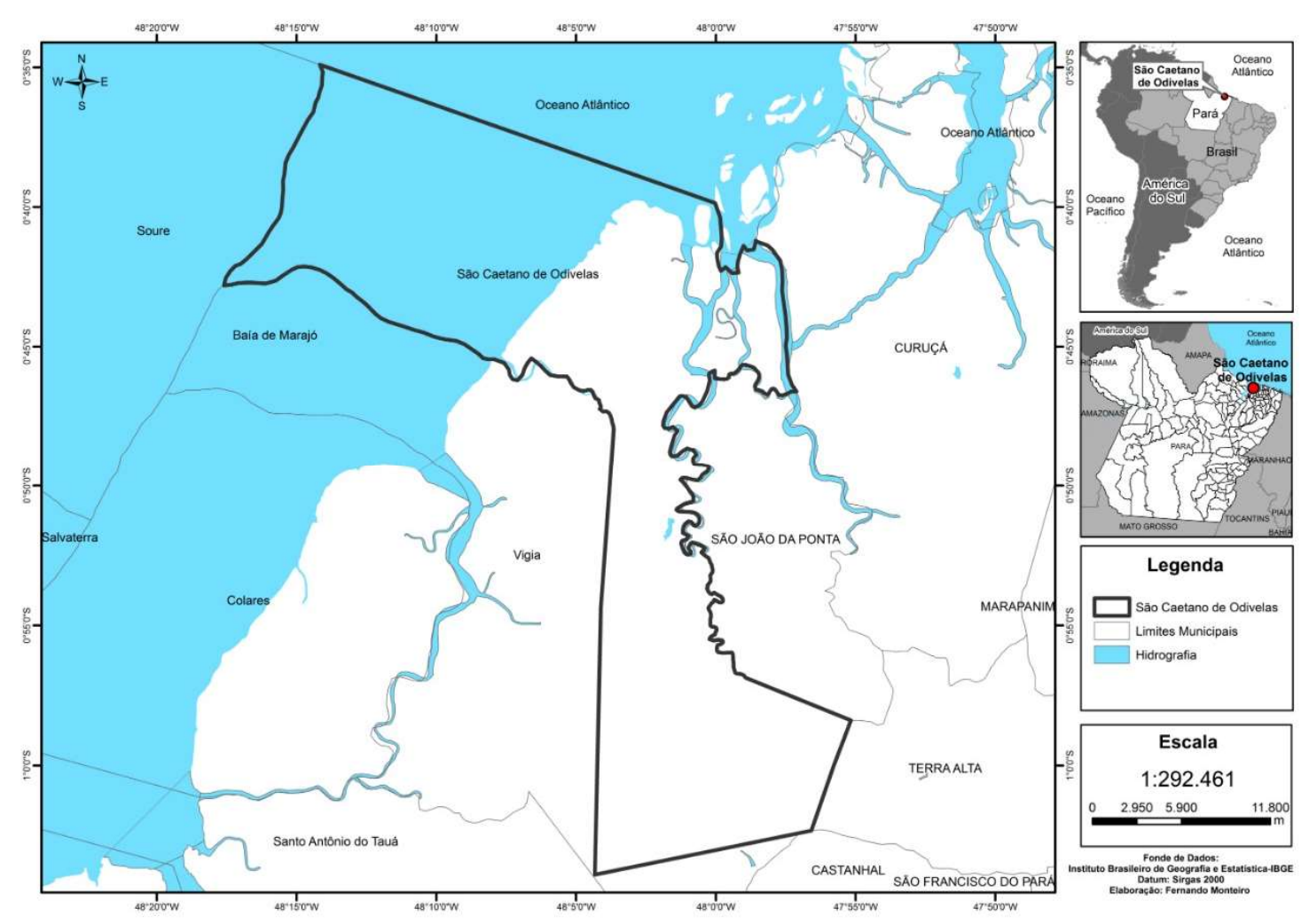

Fonte: Fernando Monteiro, 2019

Como hipótese decorrente da localização intramanguezal destas populações, enquanto finalidade estratégica de domínio do território, acreditamos que houve a utilização destas áreas para a economia, com a produção de alimentos. Além disso, as áreas são bordejadas por manguezais, sendo verdadeiros enclaves no mangue e berçários de espécies de fauna, quase sempre tendo o terreno enlameado como separação ao rio ou ao mar, com pequena extensão de terra que pode servir de ancoradouro natural. Rostain lembra que a disposição destas áreas contíguas aos cursos d'água transparentes e correntes torna estes lugares menos salubres, e as rochas dispostas na margem dos rios "permettent un accostage aisé et ne retiennent pas les raies venimeuses" (2016, p.83). A extensão restante é protegida por floresta, como uma muralha, e fosso natural; a elevação do terreno configura-se como em autênticos promontórios/falésias, de visão panorâmica privilegiada, pois 
os terrenos são da formação geológica Barreira. Por fim, os terrenos foram utilizados e o solo modificado constituindo-se por terra preta arqueológica. Esse local, apesar de possuir potencial para o desenvolvimento de grupos sociais do passado, ainda não foi pesquisado arqueologicamente de forma sistemática, mas apenas referenciado na segunda metade da década de 1960 e na década de 2000 (SIMÕES, 1981; SILVEIRA, SCHAAN, 2010; LOPES, 2016). Desta razão decorre nosso principal problema de pesquisa: por que não foram plenamente estudados? Qual a importância destes lugares para a compreensão dos movimentos e fixações de povos na região amazônica? O que eles podem relatar, como memória viva, para as populações coetâneas no sentido de construírem e afirmarem uma identidade local?

Essa análise está sendo ampliada para a península odivelense considerando a hidrografia e a diversidade dos ecossistemas, facilitadores da permanência e a subsistência dos grupos sociais no litoral paraense. Contudo, as relações de construção e subsistência também se associaram às dinâmicas climáticas (LOPES, 2016). Os sítios arqueológicos dos grupos pescadores-coletores da zona costeira paraense possuem antiguidade significativa para o povoamento da Amazônia, estando relacionados ao período Holoceno (5.705 \pm 125 anos BP; $5.280 \pm 30$ anos BP e $5.115 \pm 195$ anos BP) (ROOSEVELT, 1995; LOPES, 2016; SIMÕES, 1981).

Tendo em vista esse cenário, os objetivos de nossa pesquisa, homônima ao estudo aqui apresentado são:

a) Comprovar, mediante estudo histórico, arqueológico e etnográfico, que a região litorânea de São Caetano de Odivelas (PA) apresenta antropização que remonta ao período pré-colombiano, sendo as populações locais herdeiras da história de povos autóctones indígenas, em interação com povos transplantados;

b) Realizar pesquisa arqueológica (levantamentos preliminares e futura prospecção) no sítio Cachoeira e em outros que porventura ocorrerem na península odivelense, a fim de confirmar as hipóteses acerca da antropização longeva;

c) Levantar referencial histórico acerca do estado da arte sobre a região e também considerando suportes teóricos-metodológicos;

d) Contatar a população local para a colaboração científica, em etnografias, trabalho de campo e educação patrimonial;

e) Promover a formação científica, em grupo local de pesquisadorescolaboradores que se insira na pesquisa.

\section{Panorama da Pesquisa Arqueológica no Brasil}

Os sambaquis foram classificados pelos arqueólogos a partir da predominância de carapaças de moluscos de maneira recorrente. Krone (1908), estudando os sambaquis do Vale do Ribeira, em São Paulo, foi o primeiro a classificá-los a partir do predomínio de carapaças de diferentes espécies de moluscos; no que vários pesquisadores, que seguiam os LOPES, Paulo Roberto do Canto; FERNANDES, José Guilherme dos Santos; SILVA, Fernando Monteiro da. Povo do mangue: antropização e vestígios arqueológicos na península odivelense. Espaço Ameríndio, Porto Alegre, v. 14, n. 1, p. 265-289, jan./jul. 2020. 
preceitos do Programa Nacional de Pesquisa Arqueológica - PRONAPA também o fizeram (DIAS JÚNIOR, 1972; 1992).

Segundo Prous (1999), entre os anos de 1954 e 1956, os sambaquis do Sul e Sudeste foram estudados pelos arqueólogos J. Emperaire e A. Laming, com o intuito de testar a hipótese de P. Rivet, a respeito de migrações para a América do Sul a partir da Austrália. Os pesquisadores realizaram escavações baseadas na estratigrafia natural, bem como as primeiras radiodatações para o Brasil.

Já o discurso estabelecido pelo PRONAPA visou facilitar a atuação de arqueólogos em diversas regiões do Brasil, estabelecendo um protocolo que apontava as diretrizes teórico-metodológicas das pesquisas arqueológicas e possibilitava o seu desenvolvimento por todo o país. O PRONAPA estabeleceu as sequências culturais (tradições e fases) ${ }^{7}$ para o desenvolvimento dos grupos sociais e obtenção de dados para conhecimento das influências, migrações e difusão no território brasileiro. Nota-se, porém, a existência de pesquisas arqueológicas desenvolvidas no Sul e Sudeste do Brasil tendo como base de pesquisa a Escola Francesa (LOPES, 2016).

A Ecologia Cultural (STEWARD, 1949), utilizada pelo PRONAPA, pautou as explicações dos fatos sociais em dados ecológicos. Contudo, no Brasil, os estudos de Barreto (1999; 1999-2000), apontaram que Meggers e Evans (1970) tiveram dificuldades em sustentar suas ideias teóricas, que consideravam a cultura como parte do ecossistema e os grupos sociais como espécie natural. As investigações seriam norteadas pelas Ciências Biológicas e pelo método taxonômico, a seriação baseada no método de Ford como o instrumento de análise dos vestígios cerâmicos, considerando-se a tipologia para evidenciar mudanças ocorridas no tempo e no espaço. Estabelecia-se, dessa maneira, as tradições e as fases (MEGGERS e EVANS, 1970; 1985).

Barreto (1999; 1999-2000) postulou que os desdobramentos teóricos Neoevolucionista e da Ecologia Cultural tiveram pouco impacto na organização da Arqueologia brasileira, mesmo considerando a importância de Betty Meggers para a área. Os argumentos de Barreto, pautados pelo Determinismo tecnoambiental, e que passaram a direcionar a interpretação da ocupação pré-colombiana amazônica, foram pouco repassados aos seus orientados. Barreto $(1999 ; 1999-2000)$ ainda inferiu que mesmo categorias como o arcaico, o formativo e o clássico não se estabeleceram na Arqueologia moderna, mas, em contrapartida, o Programa Nacional de Pesquisas Arqueológicas - PRONAPA - utilizou-se das categorias denominadas tradições e fases, que buscavam identificar variantes culturais ou étnicas a partir da distribuição de artefatos no tempo ou espaço, assemelhando-se, dessa maneira, mais ao

\footnotetext{
${ }^{7}$ A tradição englobaria várias fases, compartilhando atributos presentes nos vestígios materiais: cerâmica, artefatos líticos, padrões de assentamentos, subsistência, ritual, bem como outros aspectos da cultura. A tradição apresenta grupos de elementos ou técnicas que persistem temporalmente, possuindo uma continuidade cronológica e as fases podem ter ampla distribuição geográfica e ampla persistência temporal, estas últimas podem ser definidas por meio da seriação, representando uma expressão arqueológica da comunidade etnográfica (SIMÕES, 1981; MEGGERS e EVANS, 1985; LOPES, 2016).
} 
Difusionismo Cultural europeu do que ao Neoevolucionismo americano; portanto, tais categorias marcaram a Arqueologia brasileira. Mas será que as categorias de tradição e fases podem se aplicar plenamente à realidade amazônica que ora vai se deslindando?

\section{Pesquisas arqueológicas na costa do Pará}

Nossa pesquisa tem como referência o município de São Caetano de Odivelas e procura dar seguimento ao que está posto como uma genética tradição de estudos e pesquisas na região costeira da Amazônia, inaugurando uma visão arqueológica, na área sob investigação, que promova uma arqueologia partilhada e colaborativa, desdobramento da recherche-action collaborative (BONNY, 2017, p.30). As pesquisas arqueológicas na costa norte paraense, desde o início, procuraram dar visibilidade aos sítios arqueológicos e materialidades, estimulando a cooperação entre pesquisa e as comunidades locais, além de estimular o compartilhamento de informações com estas, por meio da elaboração de plano de sensibilização de tais comunidades (LOPES, 2016).

Para efeito de sistematização, podemos considerar que Ferreira Penna (1876) é o primeiro viajante com olhar arqueológico que faz referência a sambaquis no litoral amazônico. Posteriormente, Simões, pautado em Penna, inicia estudos e prospecções no município de Quatipuru, a partir de fins dos anos 1960, na microrregião bragantina, no nordeste do Pará. Este trabalho se estende pelas décadas 1960, 1970 e 1981, a fim de se estabelecer modelos de migração no litoral amazoparaense, particularmente migrações oriundas do noroeste amazônico, desde o Caribe e a região das Guianas. Estes dois autores podem ser considerados como inauguradores dos estudos arqueológicos na região costeira, respondendo por uma primeira fase de prospecções e determinações de fases. Um segundo momento é oriundo dos estudos de Silveira e Schaan $(2005 ; 2010)$, a partir dos anos 2000, marcado por uma pesquisa com diversas abordagens a respeito dos sítios do tipo sambaqui, mas também de sociedades hierarquizadas instaladas ali, bem como a transformação do ecossistema do atual município desde o período précolombiano até a atualidade. No entanto, observou-se que as mudanças no meio ambiente afetaram diretamente os sítios arqueológicos, especialmente os sambaquis, os quais foram utilizados como matériaprima para a fabricação da cal, para a construção civil (igrejas, fortificações, residências) no período colonial, imperial e republicano no Brasil (PENNA, 1876; SIMÕES, 1970; 1981; LOPES, 2016). Este problema é particularmente grave no Nordeste paraense, região de primeira colonização portuguesa na Amazônia brasileira, datada de 1616, com a fundação da cidade de Belém. Por fim, podem-se destacar os estudos de Canto Lopes (2016), que retomam os trabalhos de Schaan e Maura, detendo-se no sítio Porto da Mina, no município de Quatipuru (PA).

Dado o estado de profunda antropização da zona costeira e regiões contíguas, muitos vestígios foram apagados pela transformação urbana do espaço. Mas as obras dos viajantes naturalistas, presentes na LOPES, Paulo Roberto do Canto; FERNANDES, José Guilherme dos Santos; SILVA, Fernando Monteiro da. Povo do mangue: antropização e vestígios arqueológicos na península odivelense. Espaço Ameríndio, Porto Alegre, v. 14, n. 1, p. 265-289, jan./jul. 2020. 
Amazônia desde meados do século XVIII, relataram sobre a utilização de conchas ou de sambaquis no Norte do Brasil, tendo como referências Henry Walter Bates (1979), João Barboza Rodrigues (1876, v. 1, 3), Domingos Soares Ferreira Penna (1876) e Charles Frederick Hartt (1885). Nesse momento, os viajantes naturalistas realizaram trabalhos detalhados de localização, inserção ambiental, nominações, mapeamento, topografia, definição das formas, dimensões, realização de coleta de superfície, intervenções por meio de escavações, interpretações de perfil, visualização de vestígios arqueológicos, observações sobre a existência de sepultamentos e suas interpretações, além do estudo da morfologia, mesmo que inicial, com a coleta de material arqueológico para análise e exposição em museus.

Foi nesse período, que os sambaquis passaram a ser nomeados: Taperinha e Pau Mulato, no baixo Amazonas; Mina do Apicuns, Mina do Tijolo, Mina de São João, Mina do Vianna, Mina da Corôa-Nova, Mina Nova e Mina do Capitão Clarindo, na costa norte paraense. De acordo com Lima (1999-2000), os naturalistas discutiram a respeito da origem dos sambaquis como resultantes do descarte de alimentação pelos indígenas, sendo acumulados ao acaso, sem clara intenção, pelos nativos; de outro modo, alguns investigadores entenderam os sambaquis como resultados de processos acumulativos naturais, associando-os ao dilúvio, que teria alterado o nível do mar.

Os naturalistas buscavam explicar a origem natural, artificial ou mista dos sambaquis, além da antiguidade dos povos americanos, sendo os artefatos o foco de análise e não o contexto em que eram encontrados. Eles buscavam, ainda, vincular as populações pré-colombianas às civilizações europeia, asiática e das Américas Central e do Sul, tidas como avançadas do ponto de vista cultural (LIMA, 1999-2000; GASPAR, 2000).

O direcionamento teórico para as pesquisas dos naturalistas foi baseado em evidências que explicam a origem e antiguidade dos povos americanos, com o intuito de elaborar possíveis rotas migratórias e de contato entre a Europa e a América, cuja base teórica está relacionada aos paradigmas evolucionista e difusionista, que consideravam não só as evidências materiais, mas também buscavam similaridades linguísticas entre populações distintas, esquadrinhando a construção genealógica e cronológica da ocupação americana (SANJAD, 2010).

Dessa maneira, a partir da década de 1920 ampliaram-se os questionamentos sobre as sociedades não ocidentais, ocorrendo à modificação da percepção do diferente e as particularidades de sociedades distintas, no qual a etnografia passou a utilizar o método de observação direta (SCHAAN, 2014), influenciando em certa medida a visão dos arqueólogos. As pesquisas de Curt Nimuendajú, na Amazônia, foram direcionadas não somente para o campo da Etnologia indígena (Amoroso, 2001), mas para abordagem de cunho arqueológico a partir de coletas e escavações de sítios arqueológicos, aplicando metodologia de descrição e interpretação de artefatos e de sítios (Nimuendajú, 1949; 1952; 2004). Pode-se considerar Nimuendajú como o precursor do campo etnológico, realizando descrição e contato de grupos indígenas, elaborando o mapa etno-histórico-linguístico de populações americanas (Nimuendajú, 1944). LOPES, Paulo Roberto do Canto; FERNANDES, José Guilherme dos Santos; SILVA, Fernando Monteiro da. Povo do mangue: antropização e vestígios arqueológicos na península odivelense. Espaço Ameríndio, Porto Alegre, v. 14, n. 1, p. 265-289, jan./jul. 2020. 
A partir do final da década de 1930, arqueólogos, aperfeiçoando as pesquisas sistemáticas, conseguiram produzir mais informações sobre as populações pré-colombianas existentes na Amazônia. Essas pesquisas foram fundamentais para o início da Arqueologia com bases teóricas e metodológicas mais definidas. Nesse momento, as pesquisas nos sambaquis foram retomadas, tornando-se importantes fontes de dados para a interpretação do modo de vida dos coletores-pescadoresceramistas na Amazônia, especialmente na zona costeira paraense (HILBERT, 1959; SIMÕES, 1981). Na área continental da Amazônia, Protásio Frikel, em 1939, realizou no sambaqui Ponta do Jauari, no município paraense de Alenquer, pesquisa arqueológica utilizando teorias, métodos e técnicas sistemáticas.

As pesquisas arqueológicas foram se desenvolvendo e se aprimorando à medida que interpretações e ideias eram aplicadas. Dessa maneira, no final da década de 1940, os métodos de análise tornaram-se mais sistemáticos para os estudos dos registros arqueológicos, especialmente na Amazônia (Meggers e Evans, 1957), sendo as informações e coleções organizadas pelos pesquisadores, no início da formação da arqueologia na Amazônia, referências importantes para as investigações arqueológicas atuais (Lopes, 2016). Nas pesquisas realizadas por Meggers e Evans em 1948 na Amazônia, os registros arqueológicos localizados foram classificados como simples, sendo exceção os vestígios arqueológicos da llha de Marajó e os contextos Megalíticos de Macapá, servindo de base para as pesquisas de Mário Simões (1981), na zona costeira paraense. A pesquisa do sambaqui fluvial $^{8}$ Ponta do Jauari, retomada por Peter Hilbert em 1959, também foi uma referência utilizada nas pesquisas da zona costeira paraense coordenadas por Mário Simões e Conceição Corrêa (HILBERT, 1959; SIMÕES, 1970; 1981).

Notou-se, com as pesquisas do século XX, uma mudança significativa na maneira de analisar os sítios arqueológicos e os ecossistemas da Amazônia, pois os sambaquis passaram a ser importantes fontes de estudo para a confirmação de teorias baseadas no histórico-culturalismo, relacionadas à ocupação de grupos sociais do litoral amazônico, às migrações vindas do noroeste e norte da América do Sul indo até o litoral da Bahia (SIMÕES, 1981; LOPES, 2016). Os sambaquis do município de Quatipuru foram importantes elos interpretativos dessa ocupação, sendo que o Porto da Mina e Ponta de Pedras tornaram-se referências para a definição da tradição e da fase Mina por Mário Simões (1981). Na época, o pesquisador notou a grande destruição dos sambaquis da costa norte paraense devido às ações naturais e antrópicas (SIMÕES, 1970; 1981).

\footnotetext{
${ }^{8}$ A elaboração do conceito de sambaqui fluvial está relacionada à implantação de sítios arqueológicos distantes da linha da costa atual. A oposição entre fluvial e linha da costa parecia fazer sentido como estratégia de classificação dos sambaquis, sendo retomada inúmeras vezes, como no caso do PRONAPA, que estabelecia que os sambaquis foram ocupados por bandos de coletores de moluscos, em que as mudanças no meio ambiente correlacionadas ao nível do mar ou, ainda, ao esgotamento dos bancos de moluscos, provocaram mudanças na base econômica, tornando-os predominantemente pescadores (GASPAR, 2000).

LOPES, Paulo Roberto do Canto; FERNANDES, José Guilherme dos Santos; SILVA, Fernando Monteiro da. Povo do mangue: antropização e vestígios arqueológicos na península odivelense. Espaço Ameríndio, Porto Alegre, v. 14, n. 1 , p. 265-289, jan./jul. 2020.
} 
As fontes bibliográficas foram fundamentais para o planejamento das análises dos vestígios materiais contidos na Reserva Técnica de Arqueologia do Museu Paraense Emílio Goeldi (MPEG), contribuindo para a reconstituição dos cenários costeiros, integrando elementos da atualidade e os paleocenários existentes nos últimos $5.570 \pm 125$ anos B.P. (ROOSEVELT, 1995), buscando caracterizar o modo de vida dos sambaquieiros, por meio dos vestígios arqueológicos e das datações (LOPES, 2016). Pelo cruzamento das fontes bibliográficas com as pesquisas arqueológicas em campo, pode-se ter um entendimento mais acurado dos cenários antropizados, dos ecossistemas abrangentes e da potencialidade das pesquisas de grupos sambaquieiros, especialmente os do litoral paraense, primeiramente em Quatipuru e agora em São Caetano de Odivelas.

Dessa maneira, mesmo constatando a existência do processo de desmonte dos sambaquis, esses sítios arqueológicos ainda podem fornecer importantes dados de pesquisa para um melhor entendimento do modo de vida dos grupos sambaquieiros e de sua relação com o paleoambiente local. As pesquisas de Mário Simões, a partir de 1962, foram influenciadas pela Arqueologia americana, baseada na escola Histórico-Culturalista. Em 1965, o investigador realizou pesquisas arqueológicas nos sambaquis do litoral paraense e maranhense até meados da década de 1970. Em 1968, um projeto de pesquisa foi apresentado com o objetivo de estabelecer as sequências cronológicas para o desenvolvimento cultural e temporal, com o planejamento de escavações, por meio de níveis artificiais de $20 \mathrm{~cm}$, num grande número de sambaquis localizado no litoral paraense, estabelecendo uma sequência para o desenvolvimento cultural e temporal, baseado na ocupação de grupos coletores-pescadores-ceramistas (SIMÕES, 1970, 1981).

Contudo, constatou-se uma significativa redução dos trabalhos de campo sobre pescadores-coletores na Amazônia entre as décadas de 1974 a 1985. Todavia, foi verificado que ocorreram pesquisas pontuais em sambaquis no rio Xingu (PEROTA, 1977; PEROTA e BOTELHO 1992; 1994), em Rondônia (MILLER, 1980; 1983) e no baixo Amazonas, nas décadas de 1970, 1980 e 1990. Os dados gerados com suas pesquisas constituem referências obrigatórias para a retomada dos estudos sobre o modo de vida dos grupos sambaquieiros do litoral paraense.

Essa irregularidade nas pesquisas voltadas tanto para sambaquis como para investigações arqueológicas no litoral paraense levou a divulgações descompassadas, sendo que os resultados preliminares das pesquisas realizadas por Mário Simões, na década de 1960 e 1970 no litoral paraense, só ocorreram em 1973 e, posteriormente, no início da década de 1980. Roosevelt $(1991,1995,1998)$ e Roosevelt et al. (1996), por sua vez, contribuíram com suas pesquisas no Sambaqui de Taperinha, realizando escavações amplas, mais detalhadas, com estudos estratigráficos de até $6,5 \mathrm{~m}$ de profundidade, realizando estudo morfológico e conseguindo datações antigas para este tipo de sítio arqueológico, bem como evidenciando a existência da cerâmica mais antiga das Américas, além de estabelecer a sua inserção na paisagem. LOPES, Paulo Roberto do Canto; FERNANDES, José Guilherme dos Santos; SILVA, Fernando Monteiro da. Povo do mangue: antropização e vestígios arqueológicos na península odivelense. Espaço Ameríndio, Porto Alegre, v. 14, n. 1, p. 265-289, jan./jul. 2020. 
Gaspar e Imazio (1999) realizaram a organização das datações dos sambaquis da Amazônia Legal por meio de estudos bibliográficos e contribuíram com a perspectiva de analisar os pescadores-coletores como grupos organizados, que tinham uma relação muito intensa com a morte, a partir dos sepultamentos.

$\mathrm{Na}$ atualidade, a partir dos anos 2000, Silveira e Schaan (2005; 2010) realizaram análise bibliográfica, observações, mapeamentos estimados, coleta de superfície e escavações pontuais em sambaquis do município de Barcarena e llha de Marajó, com os dados ainda em estudo nos laboratórios. Para o litoral maranhense, a retomada dos estudos sobre sambaquis foi realizada por Bandeira (2008; 2012), que demonstrou a inserção deles na paisagem. Além de estudá-los por meio de escavações amplas, mapeamento e coleta de vestígios, como cerâmica, estabeleceu-se a cronologia para os sambaquis e foi identificada a antiguidade da fase Mina estabelecida por Mário Simões para o litoral maranhense.

\section{A colonização da região costeira}

Muitas foram as ações que produziram mudanças significativas no uso do território costeiro, como as ações das populações sambaquieiras, as quais utilizaram intensivamente produtos naturais para a construção dos sambaquis, podendo ter impactado, por exemplo, os bancos de ostras, de mexilhões e de conchas, além da própria vegetação por meio da supressão. Os aprimoramentos técnicos para as confecções de objetos de uso cotidiano dos sambaquieiros estavam relacionados à fabricação de cerâmica, líticos, objetos de conchas, de ossos, entre outros. Também os grupos pré-colombianos agricultores poderiam ter impactado o ecossistema litorâneo, por meio da supressão vegetal, queimadas para implantação de roçados, dentre outros.

Mas o impacto das populações pré-colombianas certamente foi em menor escala se comparado ao dos colonizadores europeus, já que os impactos ambientais relacionados a estes foram: i) a construção de fortificações (paliçadas), núcleos urbanos, implantação das missões religiosas em substituição das antigas aldeias indígenas; ii) o crescimento de etnias diferentes vindas do interior e das ilhas da Amazônia misturando-as com as já existentes no litoral; iii) a fixação de cidades, vilas e povoados; iv) a construção de estradas, a exemplo da que interligou o Maranhão ao Grão-Pará; v) a supressão da floresta para a exportação da madeira e para uso na construção naval e civil; vi) a introdução de animais exóticos, como o gado, o cavalo, as galinhas, entre outros; vii) a retirada de espécies animais, de produtos vegetais e do próprio indígena, para serem apresentados nos salões reais ou como cativos; viii) a implantação das salinas; ix) a construção de igrejas, fortificações mais estruturadas e habitações; $x$ ) a utilização das rochas; a fabricação da cal proveniente dos sambaquis; xi) a utilização da mão de obra indígena na pesca e na caça, como remadores, para a construção civil, nas guerras, na limpeza dos canais, xii) disseminação de epidemias, LOPES, Paulo Roberto do Canto; FERNANDES, José Guilherme dos Santos; SILVA, Fernando Monteiro da. Povo do mangue: antropização e vestígios arqueológicos na península odivelense. Espaço Ameríndio, Porto Alegre, v. 14, n. 1, p. 265-289, jan./jul. 2020. 
entre outros (SILVEIRA, 1979; SIMÕES, 1981; CORRÊA, 1987; LOPES, 1999; SENNA, 2008; SOUZA JÚNIOR, 2010; PAPAVERO et al., 2011).

Essas transformações mais aceleradas com o colonialismo implicaram a erradicação de alguns aspectos culturais indígenas, com posterior substituição por um aparato sociocultural proporcionado pelo colonizador. Dessa maneira, a conquista europeia, depois de intensa luta pelo controle do Maranhão, do litoral nordeste do Pará e da foz do rio Amazonas, impôs suas normas, leis e instituições, possibilitando gradativas trocas culturais junto aos indígenas. Cada vez mais os indígenas que se recusavam ao contato foram sendo empurrados para o interior do continente, sem ficarem totalmente livres das influências da colonização e seus efeitos (SILVEIRA, 1979; LOPES, 1999; SOUZA JÚNIOR, 2010).

A implantação das missões religiosas, no geral em aldeamentos indígenas, provocou o aumento do volume de produtos a serem víveres aos colonizadores, a exemplo do peixe e do caranguejo para o abastecimento das vilas e lugares, que basicamente dependiam dos suprimentos provenientes das áreas rurais, próximas ou distantes da área urbana (PAPAVERO et al., 2011). Por outro lado, o avanço territorial tendo à frente os missionários, que passaram a ter controle da mão de obra indígena, utilizando o discurso de defendê-los contra a escravidão do colonizador, acaba deixando os grupos indígenas enfraquecidos pelas guerras, doença e perda de território fazendo-os optar, em sua maioria, por procurar refúgio nas missões religiosas (SILVEIRA, 1979; LOPES, 1999; SOUZA JÚNIOR, 2010).

Todavia, a documentação ainda é fragmentária levando à falta de informação ou generalização a respeito dos grupos indígenas que povoavam o litoral paraense no período do contato (PENNA, 1876; MUNIZ, 1916; SILVEIRA, 1979; SIMÕES, 1981a). Entretanto, este trabalho demonstra a existência de mudanças no pensamento histórico e arqueológico a respeito da população indígena, e a necessidade de ampliar as interpretações a respeito dos grupos indígenas povoadores do litoral da Amazônia.

Esta pesquisa demonstra que a área litorânea, rica em recursos alimentares, era utilizada desde os sambaquieiros e, provavelmente, foi palco de resistência por parte de grupos indígenas no período colonial, pois há de se imaginar que alguns indígenas permaneceram em alguns territórios litorâneos, em locais mais isolados, pois a área litorânea possuía atrativo potencial para a subsistência, e não poderia ser ignorada ou abandonada facilmente, inclusive se for levado em consideração o modelo econômico baseado na dinamização de certos grupos indígenas na obtenção de meios de subsistência, possibilitando o desenvolvimento de técnicas para o manejo de espécies vegetais, manuseio de matériasprimas, experimentação, conhecimento, qualidade dos produtos, abastecimento, entre outros.

O desenvolvimento de atividades dinâmicas demonstra, de certa maneira, o controle do território usado, tendo possibilidade de conhecer, aperfeiçoar, distribuir as matérias-primas, os produtos naturais, 
manusear as plantas, plantar roçados, construir casas, canoas e realizar a manufatura de objetos.

O conhecimento dos indígenas pode ser parcialmente percebido nas paisagens culturais, nas evidências arqueológicas, nas línguas e também nas paisagens mais preservadas do ponto de vista da vegetação, como ressalta Balée (2006). É importante perceber também a diversidade do ecossistema e o potencial da rede hidrográfica provavelmente utilizada pelos grupos sambaquieiros, que poderiam se movimentar por um vasto território por meio dos rios, igarapés e furos. A escolha do local de construção do sambaqui Porto da Mina, por exemplo, além de estratégico, pode ter sido escolhido pela facilidade de aportar e de interligá-lo aos diversos ecossistemas litorâneos (rio Campinho, Baía de Japerica, lagos, terra firme, entre outros).

\section{Os artefatos localizados no sítio Cachoeira}

O sítio arqueológico foi localizado na península odivelense (IMAGEM 2), município de São Caetano de Odivelas, na propriedade do senhor Reginaldo da Silva Rodrigues, próximo ao perímetro urbano, no bairro da Cachoeira, rua Cachoeirinha, na comunidade Santíssima Trindade, distante aproximadamente 3 quilômetros da sede municipal. Este sítio é multicomponencial, apresentando vestígios de período histórico e pré-colombiano.

Figura 2: Localização e disposição do Sítio Cachoeira
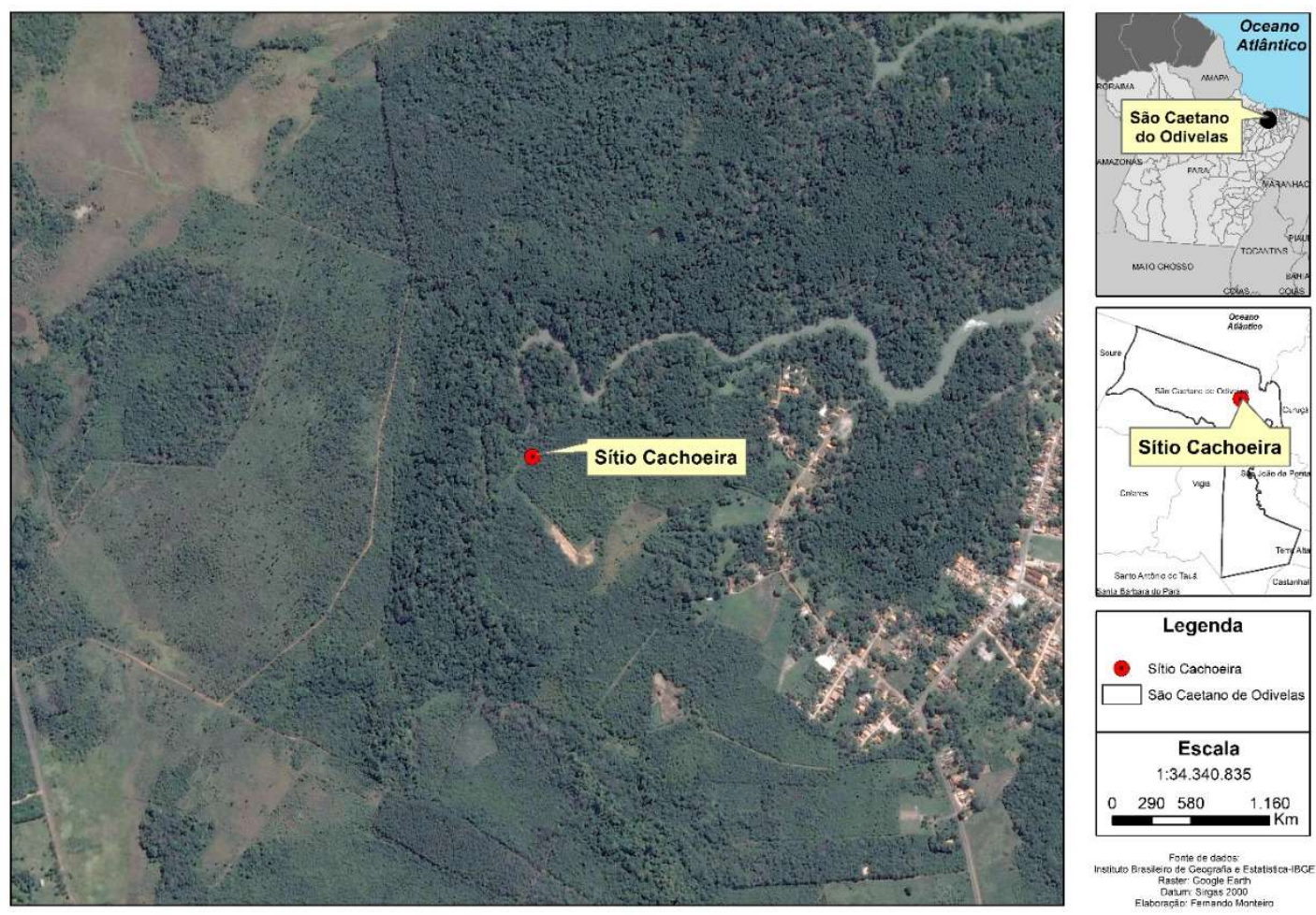

Fonte: Fernando Monteiro, 2019

LOPES, Paulo Roberto do Canto; FERNANDES, José Guilherme dos Santos; SILVA, Fernando Monteiro da. Povo do mangue: antropização e vestígios arqueológicos na península odivelense. Espaço Ameríndio, Porto Alegre, v. 14, n. 1, p. 265-289, jan./jul. 2020. 
Está posicionado em um barranco (antiga falésia), entre as confluências do mangue e da terra firme (IMAGEM 3), na margem direita de um furo onde deságua o igarapé do Manelão (IMAGEM 4), sendo também influenciado pelas águas das marés. Esta fusão entre a água doce e a água salgada, proveniente do fluxo de marés, propiciou a oferta de fauna e flora variada, com habitats diversos.

Figura 3: Borda do manguezal e terra fime

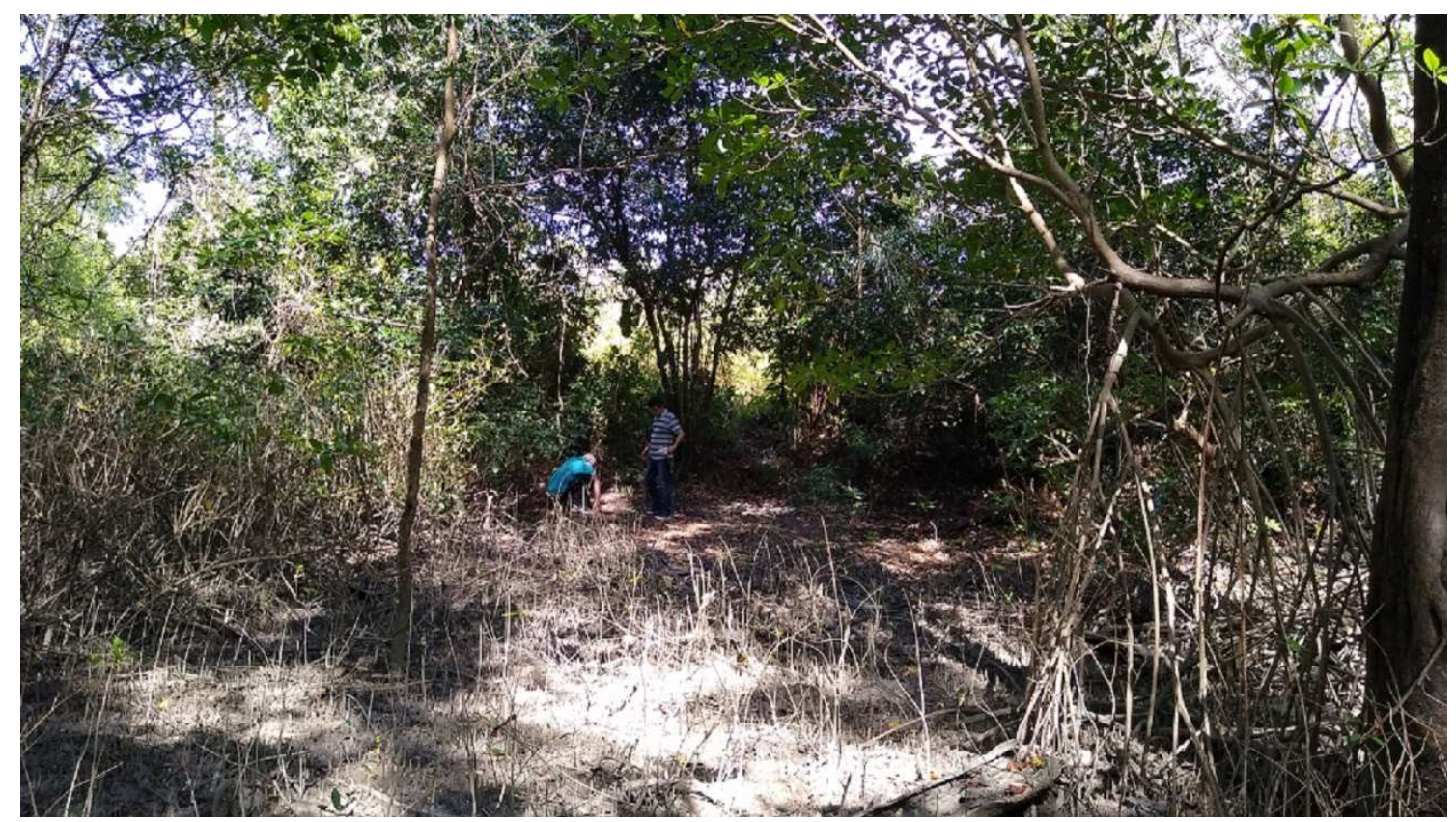

Fonte: Helisama Abreu, 2019

Figura 4: Furo e Igarapé do Manelão

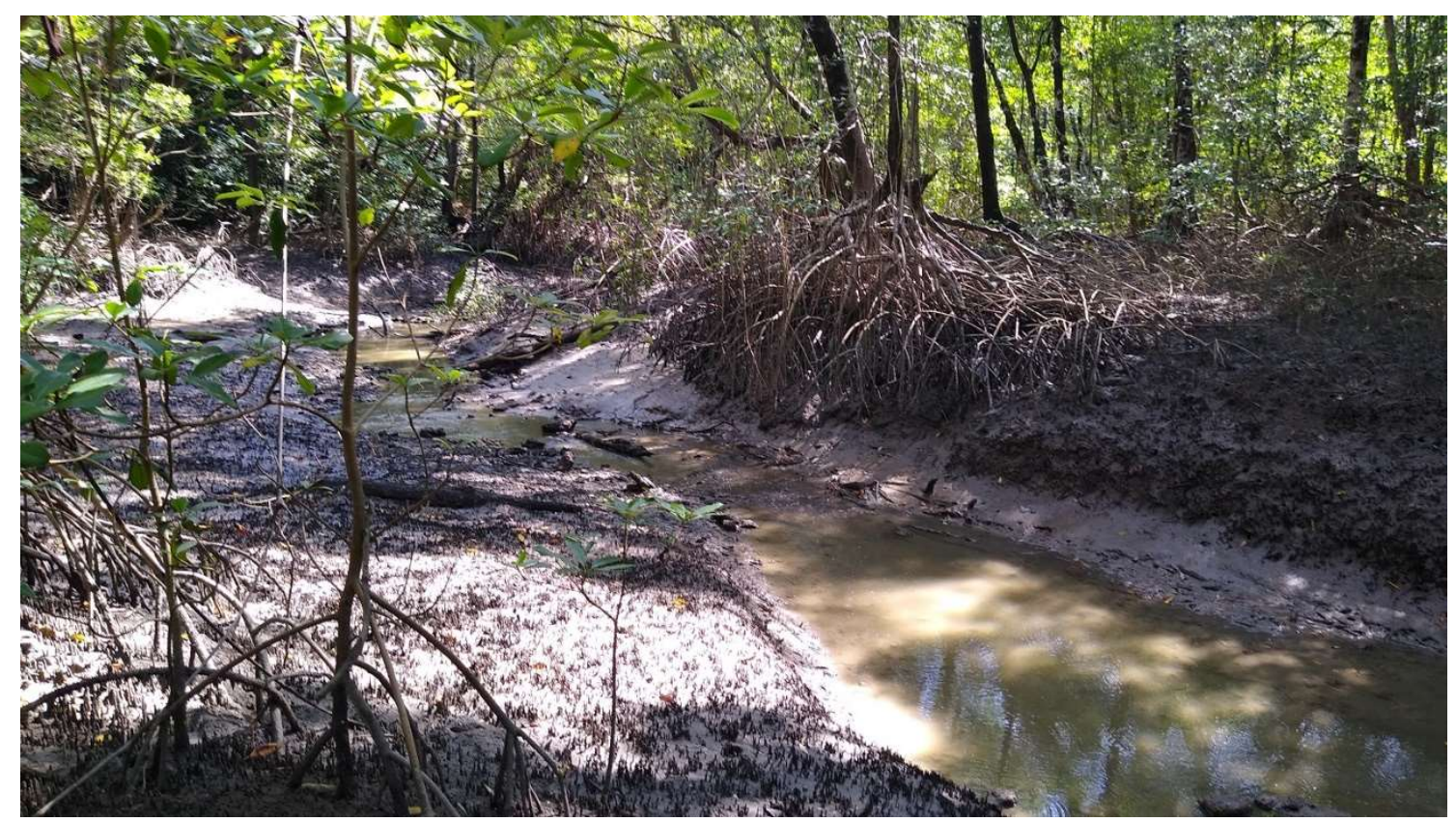

Fonte: Helisama Abreu, 2019

LOPES, Paulo Roberto do Canto; FERNANDES, José Guilherme dos Santos; SILVA, Fernando Monteiro da. Povo do mangue: antropização e vestígios arqueológicos na península odivelense. Espaço Ameríndio, Porto Alegre, v. 14, n. 1, p. 265-289, jan./jul. 2020. 
O acesso ao sítio se dá por meio de mata de capoeira que se estende pela terra firme, seguindo até a borda do manguezal, área de barranco onde o material arqueológico foi localizado disperso na superfície do solo e no próprio barranco (IMAGEM 5). Além das palmeiras, há o indicativo da existência de antiga área de roçado, o solo é de terra preta arqueológica e os vestígios localizados foram cerâmicas indígenas, lascas líticas, diversidades de louças, fragmentos de grés, metais, plásticos, ostras recentes, etc.

Figura 5: Mata de Inajá e capoeira fina na área do sítio

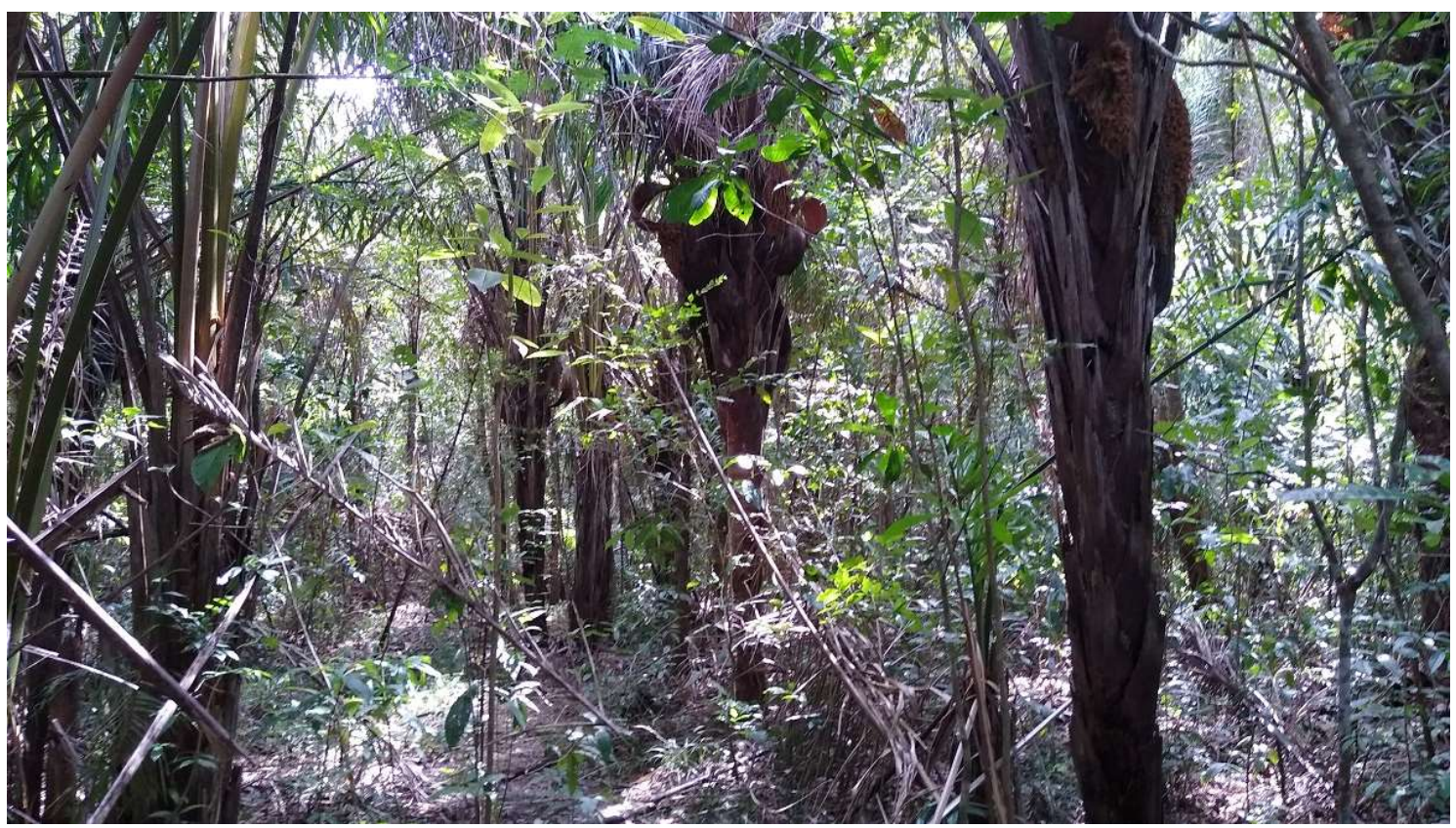

Fonte: Helisama Abreu

Os vestígios arqueológicos estavam descontextualizados, em áreas impactadas por ações naturais (quedas de barrancos), com impacto ao patrimônio arqueológico. Porém, não se realizou a coleta, nem intervenções no sítio - apenas registro fotográfico e anotações em caderneta de campo, para futuro registro junto ao Instituto do Patrimônio Histórico e Artístico Nacional (IPHAN).

Dessa maneira, o objetivo foi fotografar, inferindo, mesmo que superficialmente, sobre as características do material e do sítio arqueológico localizado, verificando a existência de ocupação précolombiana e histórica na região (IMAGENS 6 E 7). Observou-se inicialmente que a cerâmica é utilitária, com pouca decoração (incisões), porém essa é uma amostragem inicial, podendo o sítio surpreender no período de sua intervenção. 
Figura 6: Vestígio arqueológico / fragmento cerâmico

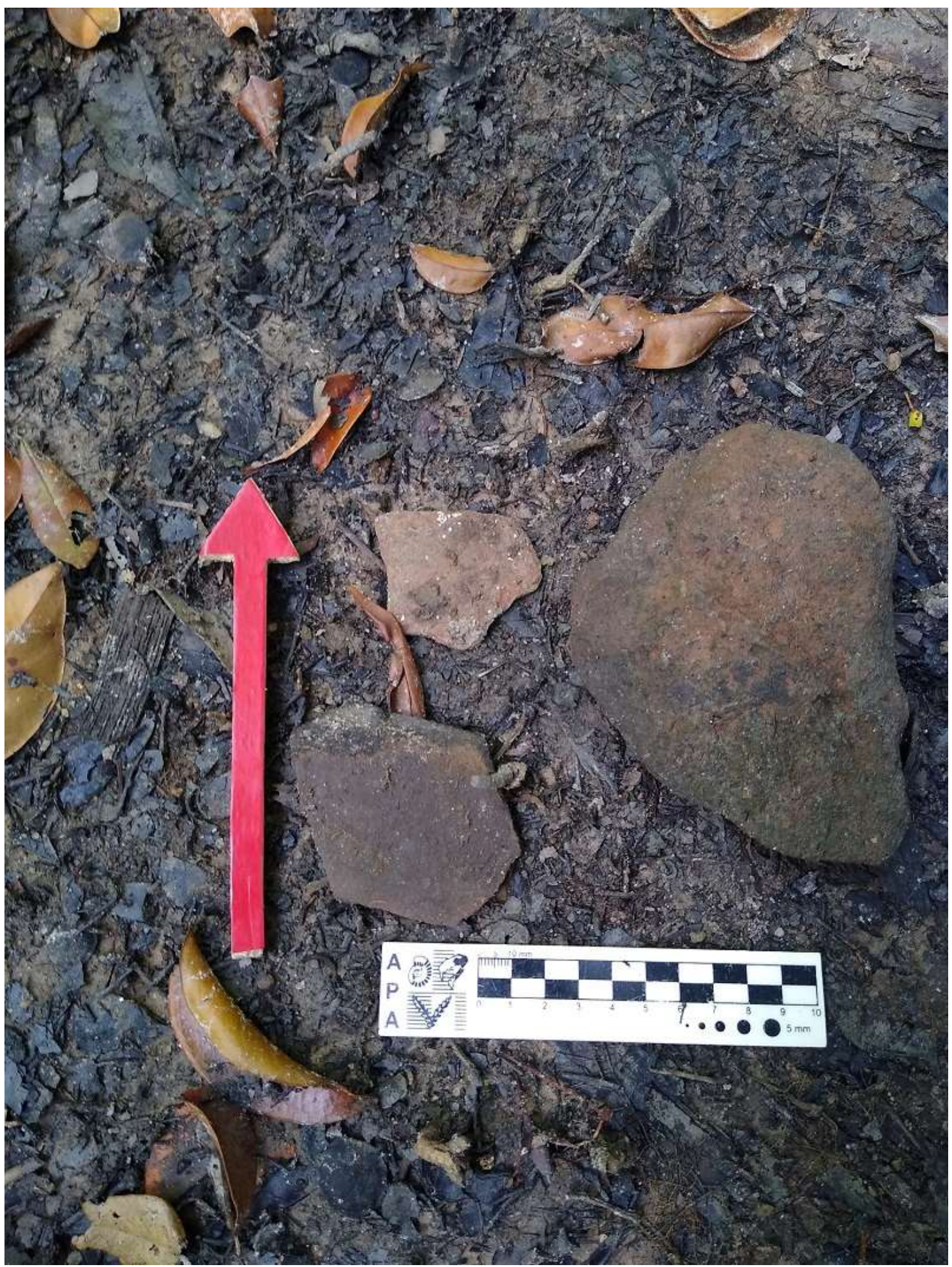

Fonte: Helisama Abreu, 2019

LOPES, Paulo Roberto do Canto; FERNANDES, José Guilherme dos Santos; SILVA, Fernando Monteiro da. Povo do mangue: antropização e vestígios arqueológicos na península odivelense. Espaço Ameríndio, Porto Alegre, v. 14, n. 1, p. 265-289, jan./jul. 2020. 
Figura 7: Fragmentos cerâmicos e louças

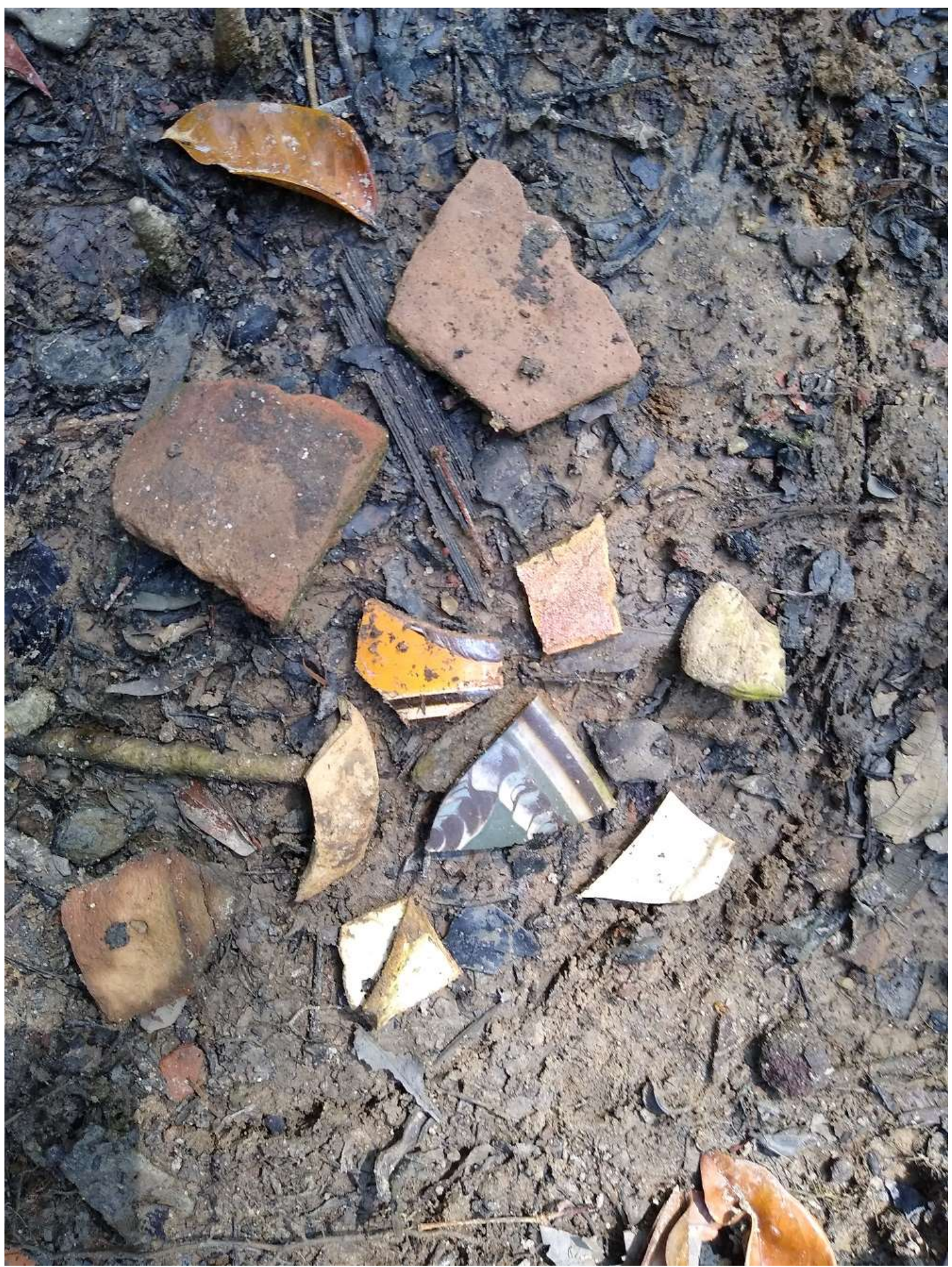

Fonte: Helisama Abreu, 2019

No pequeno bosque de terra firme com a terra preta arqueológica e as bordas do manguezal, existem árvores frutíferas, tais como cajueiro (Anacardium occidentale) e mangueira (Mangifera indica), além do açaí (Euterpe oleracea), bacaba (Oenocarpus bacaba), pupunha (Bactris gasipaes) e inajá (Attalea maripa), atrativos a pequenos animais como LOPES, Paulo Roberto do Canto; FERNANDES, José Guilherme dos Santos; SILVA, Fernando Monteiro da. Povo do mangue: antropização e vestígios arqueológicos na península odivelense. Espaço Ameríndio, Porto Alegre, v. 14, n. 1, 
pacas (Cuniculus paca), macacos (Primates), veados (Cervidae). Assim, temos nesse espaço uma oferta diversificada de produção animal e vegetal, com a garantia de um sítio relativamente seguro, em lugar estratégico e de acesso limitado, conforme a dinâmica das marés.

Ficou evidente a existência de antropização no passado, sendo a constituição do sítio o marcador da tendência para a escolha do local de fixação, exploração e transformação, além dos possíveis movimentos humanos pela zona costeira Amazônica.

\section{Conclusões Preliminares}

A potencialidade arqueológica da região é considerável se comparada a outras áreas da zona costeira paraense, pois apresenta características fundamentais para a subsistência e desenvolvimento de grupos sociais. Os sítios localizados em municípios próximos possuem características recorrentes e contribuem para a interpretação de ocupação humana antiga, inclusive o sítio arqueológico por nós denominado Cachoeira pode fazer parte de um sistema de sítios de terra preta, a exemplo do sítio Urua-Uricuri, atestado no artigo de Silveira e Schaan (2005). A provável localização deste sítio estaria nas cabeceiras do rio Mojuim, exatamente o rio que corta o município odivelense no sentido sul-norte, desaguando no Atlântico, próximo ao furo de acesso ao sítio Cachoeira. Observa-se ainda que este rio foi intitulado de Tabatinga, no período colonial, referência vinculada à existência de argila branca, própria para a produção de artefatos cerâmicos.

Certamente o domínio e controle da foz do rio Mojuim representaria, no passado pré-colombiano, a garantia de se ter uma fonte de recurso natural para a produção do instrumental para os pescadorescoletores, bem como para os agricultores - daí a localização do sítio Cachoeira, quiçá do próprio Lugar Odivelas, como atestou Baena, como ponto de observação e vigilância na foz do rio de acesso a possíveis mananciais de argila para a produção de cerâmica tão necessária à vida indígena. Lembremos que a região estuarina configurou aos povos précolombianos, localizados neste ecossistema, a possibilidade de efetiva territorialização e desenvolvimento de controle geográfico estratégico da região frente a outros grupos sociais. Assim, a península odivelense constitui-se, quase que certamente, em um rico repositório da história pré-colombiana e colonial, faltando mais incisivas investigações nesse sentido.

Um breve exemplo dessa riqueza, que pode atestar a dinâmica de povos autóctones, é a designação de um dos rios da península, o rio Pererú. Segundo Cardoso (1961) este é um étimo Caribe, que significa 'borboleta'. Ora, neste lado do estuário amazônico - o litoral paraense em que se situa a península odivelense, historicamente tem-se a presença de indígenas Tupinambá, ficando restrita a existência de população Caribe ao território da ilha do Marajó. Mas como explicar que em terras tupi exista um rio com designação de outra etnia, da outra margem da baía do Marajó? Aí está um questionamento que move nossa pesquisa e LOPES, Paulo Roberto do Canto; FERNANDES, José Guilherme dos Santos; SILVA, Fernando Monteiro da. Povo do mangue: antropização e vestígios arqueológicos na península odivelense. Espaço Ameríndio, Porto Alegre, v. 14, n. 1, p. 265-289, jan./jul. 2020. 
nos aponta uma hipótese, qual seja, das movências de povos e populações amazônidas, em lutas e acordos para a posse do território, o que será apanágio da continuação de nossas investigações. 


\section{Referências Bibliográficas}

AMOROSO, M. R. Nimuendajú às Voltas com a História. Revista de Antropologia, Vol. 44, n. 2, Universidade de São Paulo, São Paulo, 2001.

BAENA, A. L. M. Ensaio corográfico sobre a Província do Pará. Brasília: Senado Federal, 2014.

BALÉE, W. Transformação da paisagem e mudança da língua: um estudo de caso em ecologia histórica amazônica. In: ADAMS, Cristina; MURRIETA, Rui; NEVES, Walter (Ed.). Sociedades caboclas amazônicas: modernidade e invisibilidade. São Paulo: Annablume, 2006. p. 45-66.

BANDEIRA, A. M. Ocupações humanas pré-coloniais na Ilha de São Luis - MA: inserção dos sítios arqueológicos na paisagem, cronologia e cultura material cerâmica. Tese (Doutorado em Arqueologia) - Museu de Arqueologia e Etnologia, Universidade de São Paulo, São Paulo, 2012.

Ocupações humanas pré-históricas no litoral maranhense: um estudo arqueológico sobre o sambaqui do Bacanga na Ilha de São Luís - Maranhão. Dissertação (Mestrado em Arqueologia) - Museu de Arqueologia e Etnologia, Universidade de São Paulo, São Paulo, 2008.

BATES, H. W. Um naturalista no Rio Amazonas. Belo Horizonte: Itatiaia; São Paulo: EDUSP, 1979. (Coleção reconquista do Brasil).

BARRETO, C. "A construção de um passado pré-colonial: uma breve história da Arqueologia no Brasil”. Revista USP, São Paulo, n. 44, p. 32-51, dez./fev. 1999-2000.

Arqueologia brasileira: uma perspectiva histórica e comparada. Rev. Mus. Arqueol. Etnol. Supl., São Paulo, p. 201-212, 1999. Suplemento 3.

BONNY, Y. «Les recherches partenariales participatives : éléments d'analyse et des typologie ». In : GILLET, A., TREMBLAY, D-G. Les recherches partenariales et collaboratives. Québec : Press de l’Université du Québec, 2017.

CARDOSO, A. L. Toponímia brasílica. Rio de Janeiro: Biblioteca do Exército Editora, 1961.

CORRÊA, C. G. Horticultores pré-históricos do litoral do Pará, Brasil. Rev. Arqueol., v. 4, n. 2, p. 137-252, 1987.

DIAS JÚNIOR, O. F. A tradição Itaipu, Costa Central do Brasil. In: MEGGERS, Betty J. (Org.). Pré-história sudamericana: nuevas perspectivas. Washington: Taraxacum, 1992. p. 161-176.

DIAS JÚNIOR, O. F. Síntese da pré-história do Rio de Janeiro: uma tentativa de periodização. Histórica, Rio de Janeiro, ano 1, n. 2, p. 75-83, 1972. 
GASPAR, M. Sambaqui: arqueologia do litoral brasileiro. Rio de Janeiro: Zahar, 2000.

GASPAR, M. D.; IMAZIO, M. Os pescadores-coletores-caçadores do litoral norte Brasileiro. In: TENÓRIO, M. C. (Org.). Pré-história da terra brasilis. Rio de Janeiro: UFRJ, 1999. p. 247-256.

HARTT, C. F. Contribuições para a ethnologia do valle do Amazonas. Arq. Mus. Nac. Rio Jan., v. 6, p. 1-174, 1885.

HILBERT, P. P. Achados arqueológicos num sambaqui do baixo Amazonas. Belém: Instituto de Antropologia e Etnologia do Pará, 1959. (Publicação, n. 10).

KRONE, R. Informações ethnographicas do Valle do rio Ribeira de Iguape. In: COMISSÃO GEOGRAPHICA E GEOLOGICA DO ESTADO DE SÃO PAULO. Exploração do Rio Ribeira de Iguape. São Paulo: Typographia Brazil de Rothschild, 1908. p. 23-34.

LIMA, T. A. Em busca dos frutos do mar: os pescadores-coletores do litoral centro-sul do Brasil. Rev. USP., São Paulo, n. 44, p. 270-327, dez./fev. 1999-2000.

LOPES, L. O. do C. Conflito socioambiental e (Re) organização territorial: Mineradora Alcoa e comunidades ribeirinhas do Projeto Agroextrativista Juruti Velho, município de Juruti-Pará-Amazônia-Brasil. Tese (Doutorado em Desenvolvimento Rural) - Faculdade de Ciências Econômicas, Universidade Federal do Rio Grande do Sul, Porto Alegre, 2012.

LOPES, P. R. do C. Caracterização do modo de vida dos sambaqueiros que ocuparam o litoral paraense: Quatipuru, Pará, Brasil. Tese (Doutorado) Universidade Federal do Rio de Janeiro, Museu Nacional do Rio de Janeiro, Rio de Janeiro, 2016.

- A colonização portuguesa da Ilha de Marajó: espaço e contexto arqueológico-histórico na Missão Religiosa de Joanes. Dissertação (Mestrado em Arqueologia) - Pontifícia Universidade Católica do Rio Grande do Sul, Porto Alegre, 1999.

MILLER, E. T. Pesquisas arqueológicas no Território Federal de Rondônia: resultados preliminares. Programa Nacional de Pesquisas Arqueológicas na Bacia Amazônica. 1980. p. 1-23.

Relatório preliminar das pesquisas arqueológicas realizadas nos estados do Amazonas, Mato Grosso e Rondônia: resultados preliminares. Programa Nacional de Pesquisas Arqueológicas na Bacia Amazônica. 1983. p. 2-11.

MEGGERS, B. J.; EVANS, C. Archaeological investigations at the mouth of the Amazon. Washington: Smithsonian Institution, 1957. (Bulletin 167). 
A utilização de sequências cerâmicas seriadas para inferir comportamento social. Rio de Janeiro: Instituto de Arqueologia Brasileira, 1985. (Boletim série ensaios, $3)$.

Como interpretar a linguagem da cerâmica: manual para arqueólogos. Washington: Smithsonian Institution, 1970.

MUNIZ, J. de P. Município de Quatipuru. Belém: Tipografia Lauro Sodré, 1916. Tomo 9.

NIMUENDAJU, C. In Pursuit of a Past Amazon - Archaeological Researches in the Brasilian Guyana and in the Amazon Region. Goteborg: Varldskulturmuseet, 2004. 380p., il. (Etnologiska Studier, 45).

. The Tukuna. Translated by William D. Hohenthal, edited by Robert H. Lowie. Berkeley: University of California Press, 1952 (American Archaeology and Ethnology, vol. 45).

$106 \mathrm{p}$.

Os Tapajó. Boletim do Museu Paraense Emílio Goeldi, 10, Belém, 1949. 93-

Mapa Etno-Histórico do Brasil e Regiões Adjacentes. Museu Nacional do Rio de Janeiro, Rio de Janeiro, 1944.

PAPAVERO, N. et al. As notas do Padre Anselm Eckart, S. J., sobre alguns animais do estado do Grão-Pará e Maranhão (1785). Bol. Mus. Para. Emílio Goeldi. Cienc. Hum., Belém, v. 6, n. 3, p. 593-609, set./dez. 2011.

PENNA, D. S. F. Breve notícia sobre os sambaquis do Pará. Arq. Mus. Nac., Rio de Janeiro, v. 1, p. 85-99, 1876.

PEROTA, C. Relatório de trabalho de campo realizado no Rio Xingu para o Programa Nacional de Pesquisas Arqueológicas de Bacia Amazônica (PRONAPABA). Vitória: CNPQ; INPA; IPHAN; UFES, 1977.

PEROTA, C.; BOTELHO, W. C. Les sambaquis de Guara et des variations climatiques pendant l'holocène. In: PROST, M-T. (Ed.). Evolution des littoraux de Guyane et de la zone caraïbe méridionale pendant le quaternaire. Paris: Orston, 1992. p. 379-395.

PEROTA, C.; BOTELHO, W. C. Os sambaquis do guará e as variações climáticas no holoceno. Rev. Dep. Geogr., São Paulo, v. 7, p. 49-59, 1994.

PROUS, A. Arqueologia, pré-história e história. In: TENÓRIO, M. C. (Org.). Préhistória da terra brasilis. Rio de Janeiro: UFRJ, 1999. p. 19-32.

RODRIGUES, J. B. Antiguidades do Amazonas: sernambys. In: ENSAIOS de sciencia. Rio de Janeiro: Brown \& Evaristo, 1876. v. 3, cap. 4, p. 23-34.

ROSTAIN, S. Amazonie - un jardin sauvage ou une forêt domestiquée. Arles, Paris: Actes Sud, Errance, 2016.

LOPES, Paulo Roberto do Canto; FERNANDES, José Guilherme dos Santos; SILVA, Fernando Monteiro da. Povo do mangue: antropização e vestígios arqueológicos na península odivelense. Espaço Ameríndio, Porto Alegre, v. 14, n. 1, p. 265-289, jan./jul. 2020. 
ROOSEVElT, A. C. Arqueologia Amazônica. In: CUNHA, M. C. da (Org.). História dos índios no Brasil. São Paulo: Companhia das Letras, 1998. p. 53-86.

Determinismo ecológico na interpretação do desenvolvimento social indígena da Amazônia. In: NEVES, W. A. (Org.). Origens, adaptações e diversidade biológica do homem nativo da Amazônia. Belém: Museu Paraense Emílio Goeldi, p. 103-141, 1991.

Early pottery in the Amazon: twenty years of scholary obscurity. In: BANRETT, W. K.; HOOPES, J. (Ed.). The emergence of pattery: technology and innovation in ancient societies. Washington: Smithsonian Institution Press, 1995. p. 115-131.

ROOSEVELT, A. C. et al. Paleoindian cave dwellers in the Amazon: the peopling of the Americas. Science, v. 272, n. 5260, p. 373-384, 1996.

SANJAD, N. A coruja de minerva: o Museu Paraense entre o Império e a República (1866-1907). Brasília: Instituto Brasileiro de Museus, 2010. cap. 1, 2.

SANTOS, M. O dinheiro e o território. In: SANTOS, M.; BECKER, B. K. (Org.). Território, territórios: ensaios sobre o ordenamento territorial. 3. ed. Rio de Janeiro: Lamparina, 2007. cap. 1, p. 1-15.

A natureza do espaço: técnica, razão e emoção: técnica e tempo, razão e Emoção. 4. ed. São Paulo: Edusp, 2004.

. O retorno do território. OSAL: Observat. Soc. Am. Lat., Buenos Aires, ano 6, n. 16, p. 251-261, jun. 2005.

Por uma geografia nova. São Paulo: Hucitec, 1978.

SENNA, C. do S. F. de. Análise palinológica e sucessão vegetal durante o holoceno nos ecossistemas costeiros do município de Quatipuru - Pará. Belém: Museu Paraense Emílio Goeldi, 2008. Relatório de pesquisa.

SILVEIRA, I. M. da. Quatipuru: agricultores, pescadores e coletores em uma vila amazônica. Belém: Museu Paraense Emílio Goeldi, 1979.

SILVEIRA, M. I. da, SCHAAN, D. P. "Onde a Amazônia encontra o mar: estudando os sambaqus do Pará". Revista de Arqueologia, Sociedade de Arqueologia Brasileira, n. 18 , p. 67-79, 2005.

A vida nos manguezais: a ocupação humana da costa atlântica amazônica durante o holoceno. In: PEREIRA, E.; GUAPINDAIA, V. (Org.). Arqueologia amazônica. Belém: Museu Paraense Emílio Goeldi, 2010. v. 1, p. 35-48.

SIMÕES, M. F. Coletores-pescadores ceramistas do litoral do Salgado (Pará). Bol. Mus. Para. Emílio Goeldi. Antropol., Belém, n. 78, p. 1-32, 1981.

Relatório de pesquisa arqueológica na Região do Salgado (Projeto Salvamento). Belém: Museu Paraense Emílio Goeldi, 1970. 
SOUZA JÚNIOR, J. A. de. Jesuítas, colonos e índios: a disputa pelo controle e exploração do trabalho indígena. In: ALONSO, J. L. R-P.; CHAMBOULEYRON, R. (Org.). T(r) ópicos de história: gente, espaço e tempo na Amazônia (séculos XVII a XXI). Belém: Ed. Açaí; UFPA, 2010. p. 47-64.

STEWARD, J. H. South american cultures: an interpretative summary. In:

Handbook of south american indians. Washington: Smithsonian Instituion, 1949. v. 5 , parte 4, p. 669-772. (Bulletin, 143).

Recebido em: 30/12/2019* Aprovado em: 02/05/2020 * Publicado em: 11/09/2020 